\title{
A morphological, morphometrical and histological investigation of the interdigital gland in Hasmer and Hasak sheep
}

\author{
H. Kara'1 , S. Gedikli², Z. Özüdogru³ , D. Özdemir ${ }^{1}$, H. Balkaya ${ }^{1}$ \\ ${ }^{1}$ Department of Anatomy, Faculty of Veterinary Medicine, Ataturk University, Erzurum, Turkey \\ 2Department of Histology and Embryology, Faculty of Veterinary Medicine, Ataturk University, Erzurum, Turkey \\ ${ }^{3}$ Department of Anatomy, Faculty of Veterinary Medicine, Aksaray University, Aksaray, Turkey
}

[Received: 20 November 2019; Accepted: 14 January 2020]

\begin{abstract}
Background: The interdigital glands of sheep perform various functions including those pertaining to sexual behaviours. Morphological and histological structure of the gland demonstrates differences among species. The aim of this study is to examine the morphological and histological structure of Hasak and Hasmer sheep's interdigital glands and to determine the differences with other sheep breeds.

Materials and methods: For this research, we selected 7 Hasak and 7 Hasmer female sheep. After scarification, the feet were obtained and used for anatomical and histological examinations. For the histological examination, the interdigital gland tissues were stained with Crossman modified triple, periodic acid Schiff (PAS) and Alcian blue (AB) staining.

Results: The morphometric analysis results, mean values of weight, body length, body diameter, flexura, ductus length, ductus diameter, were observed as $0.80 \mathrm{~mm}$, $14.61 \mathrm{~mm}, 5.98 \mathrm{~mm}, 5.62 \mathrm{~mm}, 26.58 \mathrm{~mm}$, and $3.25 \mathrm{~mm}$, respectively in Hasak and $0.8 \mathrm{~mm}, 15.46 \mathrm{~mm}, 6.37 \mathrm{~mm}, 5.70 \mathrm{~mm}, 24.52 \mathrm{~mm}$, and $3.52 \mathrm{~mm}$ in Hasmer sheep. The histochemical staining revealed that the apocrine secretion of this gland was PAS positive and $A B$ negative.

Conclusions: The weight, body length, body diameter, flexura, ductus length and ductus diameter in the forefoot's interdigital glands of both Hasak and Hasmer sheep were higher in a statistically significant manner than those of the hindfeet's glands. (Folia Morphol 2020; 79, 4: 742-747)
\end{abstract}

Key words: Hasak, Hasmer, interdigital gland, morphometry

\section{INTRODUCTION}

Hasak and Hasmer sheep species are obtained at Konya Bahri Dagdas International Agricultural Research Institute by triple crossbreeding of the German Blackheaded Mutton, Hampshire plus Akkaraman for Hasak and Merinos for Hasmer [8, 12, 19]. After this hybridisation to increase yield characteristics, some morphological and functional alterations have formed in the body. Some characteristic specialties of Hasak and Hasmer were that mean of shearing bodyweight females was $50.65 \mathrm{~kg}$ and the male was $66.30 \mathrm{~kg}$ [7]. One of them is the skin layer and the some structures originating from the skin [2]. Interdigital gland is specialised skin structures containing all layers of the skin [21]. Skin glands such as glandula ( $g l$ ) tarsalis, gl. interdigitalis and gl. infraorbitalis, associated with reproduction in ruminants, are placed in various locations of the body [13]. These specialised gland structures' secretions also contain reproductive pheromones and have a role for sexual communication

Address for correspondence: H. Kara, PhD, Department of Anatomy, Faculty of Veterinary Medicine, Ataturk University, Erzurum 25240, Turkey, tel: +904422317188, e-mail: h.goktas@atauni.edu.tr 
with the contents being secreted [15]. Chemical secretions of the gland reportedly play an important role in the social and biological behaviours of sheep [3].

The interdigital gland is located in the cavity between the two fingers the forefeet and hindfeet in the sheep (sinus interdigitalis) and formed by the alteration of sebaceous and sweat glands with a canal opening outwards [13]. In appearance, it looks like a tobacco pipe [5]. The shape and size of the gland may vary depending on the species [1]. Histologically, the wall of this gland is formed by the epidermis, dermis and a capsule. The epidermis layer is composed of keratinised stratified squamous epithelium, and the dermis layer contains hair follicles, sebaceous glands, sweat glands, muscle fibres and apocrine glands [9]. Structural changes in these glands vary according to animal breeds and may be important for reproductive physiology.

Many publications $[1,5,8,9]$ regarding the morphology of $\mathrm{gl}$. interdigitalis are in place, yet we haven't found any studies on those of the Hasmer and Hasak sheep breeds. In this study, we aim to carry out a morphological and histological examination of the interdigital glands in Hasmer and Hasak sheep.

\section{MATERIALS AND METHODS}

\section{Animal slaughter and tissue collecting}

The animal experiments and procedures were performed in accordance with national guidelines for the use and care of laboratory animals and approved by the local animal care committee of Ataturk University. Seven female sheep from each of Hasak and Hasmer used in the study were procured from Konya Bahri Dagdaş International Agriculture Institute. All sheep were fed with standard ruminant nutrition for the mating season [20]. Arteria carotis communis of the anesthetised (utilising xylazine $\mathrm{HCl}[0.2 \mathrm{mg} / \mathrm{kg} \mathrm{IV}]$ and ketamine $\mathrm{HCl}[2.2 \mathrm{mg} / \mathrm{kg} \mathrm{IV}]$ ) sheep were cut in the neck and their blood was drained. Then the interdigital glands of the materials were dissected and removed through the nails and then morphometric measurements and morphological examinations followed macroscopic photographing. Weights, body widths, body lengths, flexures, drainage channel widths and lengths of the morphometrically dissected interdigital gland of both species were measured.

\section{Histologic analysis}

After morphological and morphometric examinations, tissues fixed in $10 \%$ formaldehyde solu- tion were, after the washing process, subjected to dehydration and alcohol series and embedded in paraffin blocks. Then, cross-sections of 5-7 $\mu$ were taken and Crossman-modified Mallory triple staining, periodic acid Schiff (PAS) and Alcian blue (AB) staining were performed and histologically examined under high-power light microscopy (Nikon Eclipse i50, Tokyo, Japan).

\section{Statistically analysis}

All data are presented as mean \pm standard deviation values. Differences between the groups were analysed by the paired t-test. Statistical differences were considered significant at $p<0.05$.

\section{RESULTS}

\section{Anatomical results}

When the two nails were opened in the dissection, the phalanx media and the phalanx proximalis border area contained the drainage channel hole of the gland and the proximal portion of the drainage channel. The body of the gland was found in the area between the phalanx media (Fig. 1A, B). The interdigital gland of the forefeet was larger than the interdigital gland of the hindfeet in both breeds studied (Fig. 1C, D).

The interdigital gland of both breeds in both forefeet and hindfeet looked like a tobacco pipe and consisted of two main parts: body and drainage channel. The drainage channel was observed to be significantly longer than the body and was found to be connected to the body by a flexura (Fig. 1C, D). The drainage channel was observed to open with a hole to the outside and the hole was located in the dorsocranial of the foot, about $2-2.5 \mathrm{~cm}$ above the border of the nail and hairs, levelling with the articulatio interphalangia proximalis. The presence of thin dark hairs extending through the hole was observed (Fig. 1C, D).

\section{Histological results}

Histological examination of the interdigital gland sections of the Hasak and Hasmer sheep revealed that the wall of this tissue consisted of three layers from the lumen on: epidermis, dermis and fibrous capsule. Dermis was composed of various structures such as sebaceous glands, hair follicles, musculus arrector pili and sweat glands. Each hair follicle of different size was surrounded by connective tissue and the musculus arrector pili located close to the hair follicles was easily visible. In the sebaceous glands 

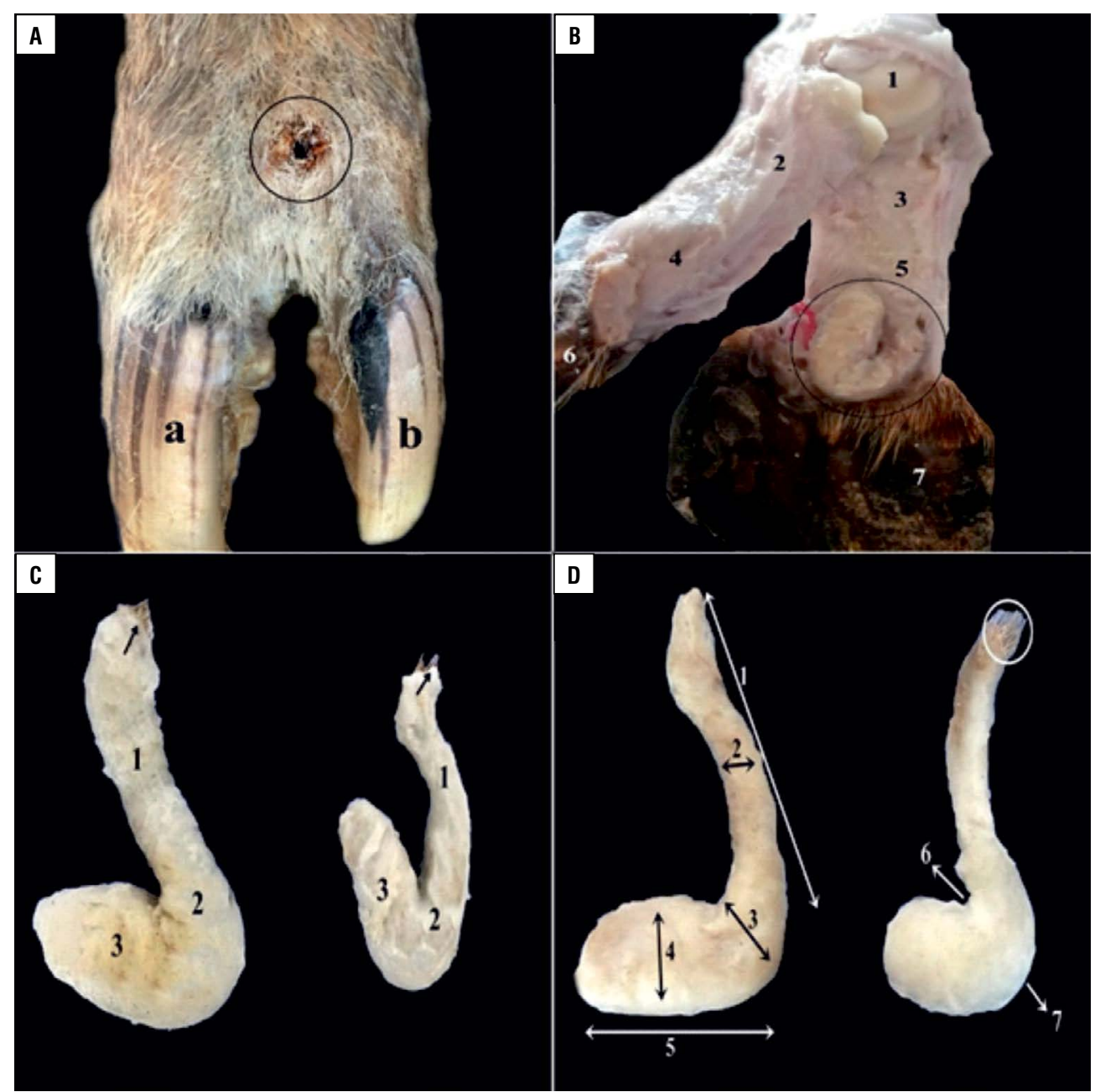

Figure 1. Photograph of Hasmer ve Hasak sheep's interdigital glands; A. Dorsal view of Hasmer sheep' forefoot, a — phalanx distalis-capsula ungula (medial), b - Phalanx distalis-capsula ungula (lateral), circle — orificium externa of interdigital gland; B. Medio-leteral view of Hasak sheep's forefoot, 1 - caput metacarpalis, 2 - phalanx proximalis (medial), 3 - phalanx proximalis (lateral), 4 - phalanx media (medial), 5 - phalanx media (lateral), 6 - phalanx distalis-capsula ungula (medial), 7 - phalanx distalis-capsula ungula (lateral), circle - interdigital gland; C. Interdigital glands of forefoot and hindfoot of Hasmer sheep (the left one is forefoot's interdigital gland, the right one is hindfoot's interdigital gland), 1 -ductus of interdigital glands, 2 - flexura, 3 - body of interdigital gland, arrow - ductus of interdigital gland; D. Interdigital glands of forefeet and hindfeet of Hasak sheep (the left one is forefoot's interdigital gland, the right one is hindfoot's interdigital gland), 1 - ductus length, 2 - diameter of ductus, 3 - flexura length, 4 - body diameter, 5 - body length, 6 - internal angle of flexura, 7 external angle of flexura, circle - ductus of interdigital gland.

arranged as clusters of acinus, it was determined that the acinus was made of cells of different sizes. In the lower parts of the dermis were identified apocrine secreting glands, forming the parenchyma of the sinus interdigitalis (Fig. 2).

It was observed that these apocrine glands were more intense in the interdigital gland located in the forefeet in both the Hasmer and Hasak breeds, whereas the interdigital gland in the hindfeet had more sebaceous glands and collagen threads. PAS and AB staining demonstrated PAS positive reaction in some parts of the apocrine secreting glands' lumens in both species (Fig. 2); however, $A B$ positive reaction was not detected. Because there is no $A B$-positive reaction, we did not put a figure.

\section{Statistical results}

In the morphometric analysis, all values of forefeet were compared with hindfeet as well as these values of Hasmer and Hasak sheep were compared with each other as seen in Table 1.

Statistical comparison of the morphometric findings revealed differences in the interdigital gland's weight, body length, body diameter and ductus length parameters between the forefeet and hindfeet 


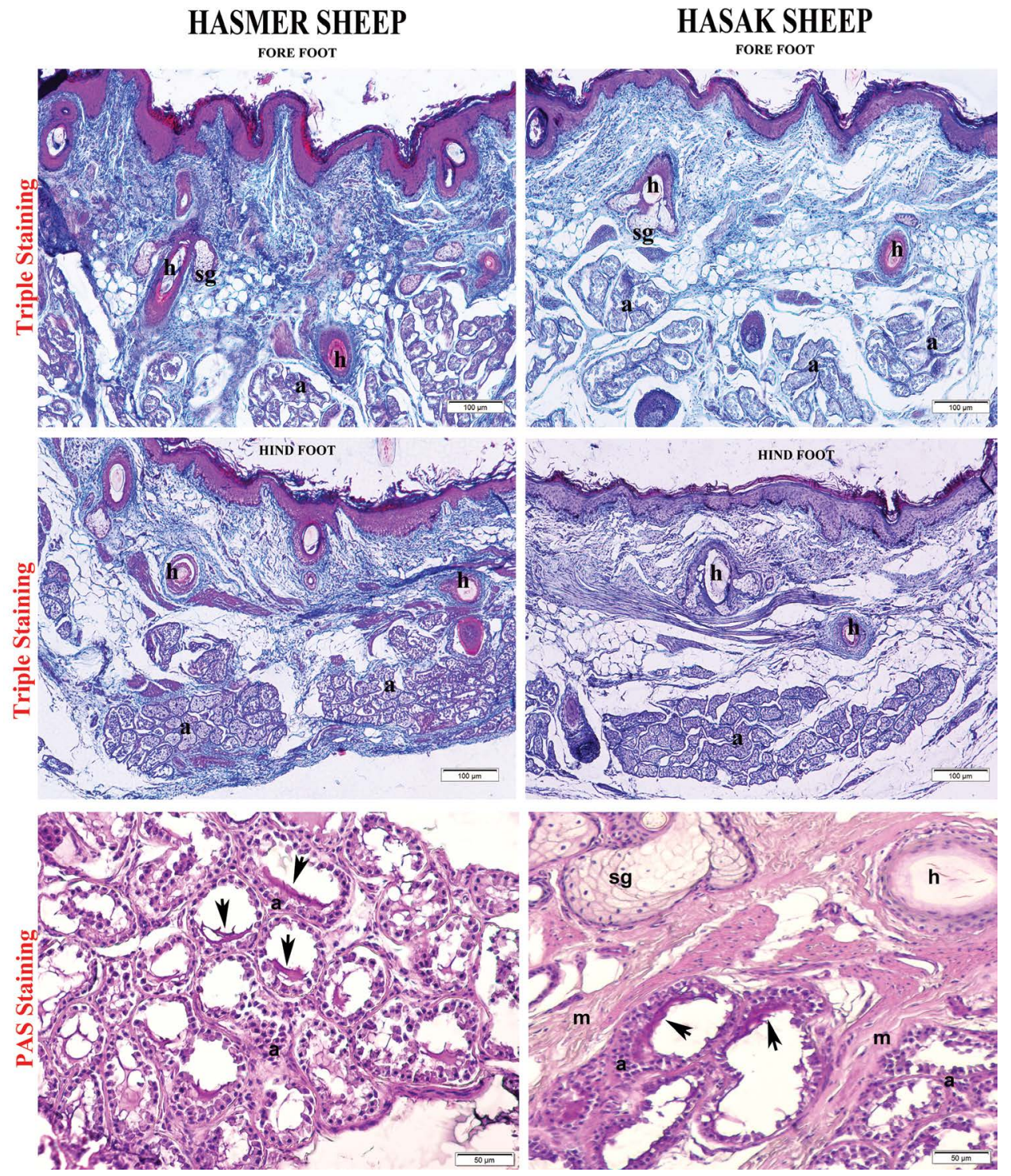

Figure 2. Histologic illustration of Hasmer and Hasak sheep's interdigital glands; $\mathrm{h}$ - hair follicle, $\mathrm{sg}$ - sweat gland, $\mathrm{m}$ - musculus arrector pili, a - apocrine gland, arrow head — apocrine secretion positive for periodic acid Schiff (PAS) staining, Crosman modified Mallory's triple staining and PAS staining.

of the Hasak sheep $(p<0.05)$. Flexura and ductus diameter parameters were not statistically significant $(p>0.05)$. In addition, no statistical difference was found in the comparison of parameters of the interdigital gland of Hasmer and Hasak sheep $(p>0.05)$. Further, when comparing the mean of these parameters between Hasmer and Hasak sheep, it was determined that the measurement values of body length, body diameter, flexura, body length and body diameter were not statistically significant when compared with each other $(p>0.05)$. All statistical evaluations and comparisons are presented in Table 1.

\section{DISCUSSION}

In our study, it was found that interdigital gland was localised between the fingers of the fore and hind feet in sheep; it looked like a pipe in shape; it had a drainage channel that opened out through a hole; the gland body and drainage channel were between the phalanx medias and the drainage channel hole was at the same level with articulatio interphalangia proximalis and inside was a small amount of dark hair. These findings are similar to previous studies $[4,5,9,21]$. Unlike our findings, Karahan et al. [11] reported that this gland was found in rudimentary 
Table 1. Morphometric analysis of Hasmer and Hasak sheep's interdigital glands for gland weight, body length, body diameter, flexura, ductus length and ductus diameter values

\begin{tabular}{|c|c|c|c|c|c|c|c|}
\hline Race & Direction & $\begin{array}{l}\text { Weight } \\
\text { [g] }\end{array}$ & $\begin{array}{l}\text { Body length } \\
\text { [mm] }\end{array}$ & $\begin{array}{c}\text { Body diameter } \\
\text { [mm] }\end{array}$ & $\begin{array}{c}\text { Flexura } \\
{[\mathrm{mm}]}\end{array}$ & $\begin{array}{c}\text { Ductus length } \\
\text { [mm] }\end{array}$ & $\begin{array}{c}\text { Ductus diameter } \\
{[\mathrm{mm}]}\end{array}$ \\
\hline \multirow[t]{4}{*}{ HASAK } & Forefeet (A) & $1.04 \pm 0.12^{\mathrm{a}}$ & $16.33 \pm 0.92^{a}$ & $6.73 \pm 0.41^{\mathrm{a}}$ & $5.85 \pm 0.63^{\mathrm{a}}$ & $29.65 \pm 0.82^{\mathrm{a}}$ & $3.60 \pm 0.33^{\mathrm{a}}$ \\
\hline & Hindfeet (B) & $0.56 \pm 0.07^{\mathrm{b}}$ & $12.89 \pm 0.66^{b}$ & $5.24 \pm 0.45^{b}$ & $5.40 \pm 0.14^{\mathrm{a}}$ & $23.51 \pm 1.21^{\mathrm{b}}$ & $2.91 \pm 0.11^{\mathrm{a}}$ \\
\hline & $\mathrm{P}$ (by direction) & 0.005 & 0.025 & 0.014 & 0.569 & 0.002 & 0.061 \\
\hline & Mean $(A+B)$ & $0.80 \pm 0.32$ & $14.61 \pm 0.45$ & $5.98 \pm 0.55$ & $5.62 \pm 0.38$ & $26.58 \pm 0.81$ & $3.25 \pm 0.24$ \\
\hline \multirow[t]{5}{*}{ HASMER } & Forefeet (A) & $1 \pm 0.32^{\mathrm{a}}$ & $17.25 \pm 1.09^{a}$ & $7.15 \pm 0.91^{\mathrm{a}}$ & $6.37 \pm 1.01^{\mathrm{a}}$ & $26.39 \pm 2.22^{\mathrm{a}}$ & $3.77 \pm 0.71^{\mathrm{a}}$ \\
\hline & Hindfeet (B) & $0.60 \pm 0.13^{b}$ & $13.67 \pm 0.85^{b}$ & $5.59 \pm 0.20^{b}$ & $5.02 \pm 0.51^{\mathrm{a}}$ & $22.64 \pm 2.30^{\mathrm{b}}$ & $3.27 \pm 0.57^{a}$ \\
\hline & $\mathrm{P}$ (by direction) & 0.015 & 0.03 & 0.02 & 0.082 & 0.01 & 0.11 \\
\hline & Mean $(A+B)$ & $0.8 \pm 0.28$ & $15.46 \pm 0.89$ & $6.37 \pm 0.63$ & $5.70 \pm 0.45$ & $24.52 \pm 0.280$ & $3.52 \pm 0.88$ \\
\hline & $\mathrm{P}$ (by race) & \multicolumn{6}{|c|}{ No statistical differences between Hasak and Hasmer sheep } \\
\hline
\end{tabular}

The values were expressed as arithmetic means \pm standard deviation. ${ }^{a, b}$ betters shows the statistically significant difference $(p<0.05)$ between the forefeet and hindfeet groups

form in goats, while Janicki et al. [10] reported that there was no interdigital gland in the forefeet of the male deer.

In previous studies, histological and morphological structures of the interdigital glands of the Lori's [1], Yankasa [17], Tuj [3], Akkaraman [11], and Karagouniko [16] sheep, in concurrence with our study, determined that the histological structure of the interdigital gland consisted of three layers, which are epidermis, dermis and fibrous capsule. However, Pourlis et al. [16] suggested that the ovine interdigital sinus possesses a sweat glandular component that features double secretor activity. Aslan et al. [3] similar to our study, found out that the sebaceous, sweat, and apocrine glands, muscle fibres, nerve plexus, and hair follicles to be existing in the dermis layer of the Tuj breed sheep. However unlike this study [16], it was determined that interdigital gland of Hasak and Hasmer sheep had no lymph node and that there were more apocrine secreting glands in the forefeet than in the hindfeet. It was found that the interdigital gland in the hindfeet mostly contained sebaceous glands and collagen threads.

Histochemical staining proved that the interdigital gland's apocrine secretory was in neutral glycoprotein structure (PAS positive reaction) and the acidic glycoprotein structure was negative ( $A B$ negative). Awaad et al. [5] and Parillo and Diverio [15] in their studies with Baladi sheep and fallow deer (Dama dama) respectively determined that their secretory structures were similar to those of Hasak and Hasmer sheep. On the contrary, Abbasi et al. [1] reported that in Lori sheep interdigital gland's secretory acini were of acidic glycoprotein (AB positive) structure and neutral glycoprotein (PAS staining) was negative. We concluded that the secretions of the interdigital glands may have different chemical structures according to species and breeds.

Forefeet and hindfeet interdigital gland weight was measured respectively as $1.05 \mathrm{~g}$ and $0.56 \mathrm{~g}$ in Hasak and $1 \mathrm{~g}$ and $0.6 \mathrm{~g}$ in Hasmer sheep. However, it was $0.84 \mathrm{~g}$ in the curly sheep according to Suzer et al. [18] and $1.16 \mathrm{~g}$ (average weight of the forefeet and hindfeet's interdigital glands) in male and female Iranian domestic sheep according to Abbasi et al. [1]. Similar with our findings, the size of interdigital glands in forefeet are larger than in the hind feet were found by Atoji et al. [6] in Japanese serow and Abbasi et al. [1] in Lori's sheep. On the other hand, some studies were found no differences between the size and shape of the interdigital sinus in forefeet and hindfeet of sheep [21]. The morphologic differences of interdigital gland between forefeet and hindfeet in Hasak and Hasmer sheep were related with hypothesis that it plays a role in sexual communication.

In Hasak and Hasmer sheep, the lengths of the glands were determined as $14.61 \mathrm{~mm}$ and $15.46 \mathrm{~mm}$ and their diameters were $5.98 \mathrm{~mm}$ and $6.37 \mathrm{~mm}$, respectively. Measurements for the Hemshin sheep were $9.29 \mathrm{~mm}$ and $20.90 \mathrm{~mm}$ in the forefeet and $7.48 \mathrm{~mm}$ and $18.95 \mathrm{~mm}$ in the hindfeet. In Egyptian native breeds of sheep the length was reported as $15 \mathrm{~mm}$ and the diameter as $2 \mathrm{~mm}$ [5]. Abbasi et al. [1] found such parameters as $26 \mathrm{~mm}$ and $49 \mathrm{~mm}$ and Misk and Misk [14] determined the length 
of the gland to be $25 \mathrm{~mm}$ and the diameter as $6 \mathrm{~mm}$. Ductus length was measured as $23.51 \mathrm{~mm}$ and $22.64 \mathrm{~mm}$ in Hasak and Hasmer sheep respectively in our study, while this value was found to be $21.9 \mathrm{~mm}$ in curly sheep [8], $26.06 \mathrm{~mm}$ in Iranian domestic sheep [1], $26.81 \mathrm{~mm}$ in Awassi sheep [22] and $30 \mathrm{~mm}$ in adult Saedi sheep [14]. The values of Hemshin sheep [9] were measured as $19.92 \mathrm{~mm}$. The findings of the mentioned studies were similar to our findings.

\section{CONCLUSIONS}

The morphometric and histological characteristics of the interdigital gland of Hasak and Hasmer sheep crossbreeding suggest that they are nearly similar to those of other sheep breeds. It is supported by studies that differences in some parameters vary depending on the differences in life condition and nutrition factors, but these morphometrical and histological differences cannot cause a major change in the physiology of interdigital gland. The findings of this study will form the basis of future sexual function studies in Hasak and Hasmer sheep.

\section{Acknowledgements}

Financial support for this work was provided by the Atatürk University Scientific Research Foundation.

\section{REFERENCES}

1. Abbasi M, Gharzi A, Mohammadzadeh S, et al. Morphology and histology of the interdigital gland in an Iranian native breed of sheep. J Anim Vet Adv. 2009; 8: 1157-1161.

2. Akmaz A, Tekin M, Kadak R, et al. Anadolu (Konya) Merinosu, Hampshire Down x Anadolu Merinosu ve Alman Siyah Baş $\mathrm{x}$ Anadolu Merinosu f1 ve $\mathrm{g} 1$ kuzularında besi ve karkas özellikleri. Türk J Vet Anim Sci. 1999; 3: 507-515.

3. Aslan K, Kürtül I, Nazlı M, et al. Morphologic features of the interdigital sinus of the Tuj sheep. Kafkas Univ Vet Fak Derg. 2010; 16: 623-626.

4. Avdic R, Katica A, Mlaco N, et al. Morphological characteristics of interdigital diverticulum (sinus cutaneous interdigitalis) of Dubska Pramenka. Biotehnologija u stocarstvu. 2013; 29(3): 441-448, doi: 10.2298/bah1303441a.

5. Awaad AS, Tawfiek MG, Moawad UK, et al. Morphohistological and surgical anatomy of the sinus interdigitalis in Egyptian native breeds of sheep. Beni-Suef University J Basic Applied Scien. 2015; 4(2): 157-166, doi: 10.1016/j. bjbas.2015.05.010.

6. Atoji $Y$, Suzuki $Y$, Sugimura M. Lectin histochemistry of the interdigital gland in the Japanese serow (Capricornis crispus) in winter. J Anat. 1988; 161: 159-170.
7. Canatan T, Kan M, Kırbaş M, et al. Adult live weight estimates of Hasmer and Hasak sheep with their some body measurements. Conference Paper in Balkan Agriculture Congress, 08-10 Sept. ; 2014: Edirne.

8. Demiraslan $Y$, Akbulut $Y$, Deprem T, et al. Morphological and morphometrical characteristics of the interdigital gland in Kivircik sheep. Turk J Vet Anim Sci. 2014; 38: 485-489, doi: 10.3906/vet-1403-21.

9. Gürbüz I, Demiraslan Y, Sarı EK, et al. Morphologic and morphometric structure and arterial vascularization of glandula interdigitalis in male hemshin sheep. Kafkas Univ Vet Fak Derg. 2017; 23: 241-246.

10. Janicki Z, Hraste A, Slavica A, et al. Morphohistological characteristics of the interdigital gland in the roebuck (Capreolus capreolus L. Vet Arh. 2003; 73: 27-38.

11. Karahan S, Yildiz D, Bolat D. Scanning electron microscopic features of the ovine interdigital sinus. Acta Vet Hung. 2007; 55(4): 417-424, doi: 10.1556/AVet.55.2007.4.1, indexed in Pubmed: 18277701.

12. Kaymakçı M, Taşkın T, et al. Türkiye koyunculuğunda melezleme çalışmaları. Hayvansal üretim. 2008: 49.

13. König HE, Liebich HG. Veterinary anatomy of domestic mammals: textbook and colour atlas, Schattauer Verlag 2013.

14. Misk T, Misk N. Surgical Excision of Interdigital Pouch and Cyst in Sheep. Int J Veterinary Med Res Rep. 2013: 1-8, doi: $10.5171 / 2013.187394$.

15. Parillo F, Diverio S. Glycocomposition of the apocrine interdigital gland secretions in the fallow deer (Dama dama). Res Vet Sci. 2009; 86(2): 194-199, doi: 10.1016/j. rvsc.2008.08.004, indexed in Pubmed: 18809187.

16. Pourlis AF. Functional morphological characteristics of the interdigital sinus in the sheep. Folia Morphol. 2010; 69(2): 107-111, indexed in Pubmed: 20512761.

17. Sivachelvan MN, Yahaya A, Chibuzo GA. Developmental changes in the interdigital pouch of Yankasa sheep. Small Ruminant Res. 1992; 9(3): 303-312, doi: 10.1016/09214488(92)90159-2.

18. Süzer B, Akkoç CGÖ, Arican I, et al. Morphological and immunohistochemical features of interdigital sinus in Kivircik sheep. Kafkas Univ Vet Fak Derg. 2016; 22: 69-73.

19. Teke BE, Özüdoğru Z, Özdemir D, et al. Hasak koyunlarında kalp kas köprüleri ve koroner arterler. Bahri Dağdaş Hayvancılık Araştırma Dergisi. 2017; 6: 1-12.

20. Tekin ME, Gürkan M, Karabulut O, et al. Performance testing studies and the selection of Hasmer, Hasak, Hasiv and Linmer crossbreed sheep types: III. Fattening performance. Turk J Vet Anim Sci. 2005; 29: 67-73.

21. Uğurlu S. Koyunlarda sinus interdigitalislerin ışık mikroskobik yapısı üzerine incelemeler. İstanbul Univ Vet Fak Derg. 1991; 17: 1-7.

22. Yilmaz B, Yilmaz R, Demircioğlu i, et al. Morphological and histological structure of the interdigital gland in Awassi sheep (Ovis aries). Turk J Vet Anim Sci. 2017; 41: 380-386, doi: 10.3906/vet-1605-8. 